\title{
Future of Technologies in the Agricultural Sector
}

\author{
Taran N.V, Krasnorutskyy O.O, Reznik N.P, Slobodianyk A.M, Guley S.A.
}

\begin{abstract}
High technologies have penetrated into all spheres of production, and recently they have been applied even in such traditional industries as agriculture. Technology development also has influence on the appearance of new company functions and motivates the appearance of new professions and new types of services. In order to understand the future of innovative development in the field of agricultural enterprises, it is necessary to forecast what technologies the future and what related professions will arise in the near tomorrow. In addition, we need to know what condition of this market is now, which areas are actively developing, and which are only just beginning to be implemented into the agricultural sector. This paper answers on these questions.
\end{abstract}

Keywords: agrarian business, Blockchain, market of technologies, precision farming.

\section{INTRODUCTION}

Agrarian business is changing rapidly. The development of technology and new technical investigations force farmers to implement new and to compete with each other. Habitual combines and seeders are modified beyond recognition, the number of workers per 1 ha of farmland is reduced significantly. Nevertheless, the FAO (Food and Agriculture Organization of the United Nations) [1] continues to talk about the threat to food security. External factors which have influence on the productivity and saturation of the market with food often reduce supply in the face of growing demand. Therefore, the first position is the need to implement new technologies into the agricultural sector, which will help to solve emerged problems and respond in time to adverse changes of climate, of the environmental and other factors. What is the near future of agriculture? What changes is expected and what should be prepared for? What technological innovations in the agrarian sector have already taken its niche among world producers of agricultural crops, and what are just starting to gain popularity?

The main goal of the paper is to find out the current condition of things in the agricultural technology market, to demonstrate the effect of technology implementation in different regions of the world and to define the future of technological innovations and services in the agricultural sector.

Revised Version Manuscript Received on 15 September, 2019.

Taran N.V., Kharkiv Petro Vasylenko National Technical University of Agriculture, Kharkiv, Ukraine. (Email: nb500907@gmail.com)

Krasnorutskyy O.O., Kharkiv Petro Vasylenko National Technical University of Agriculture, Kharkiv, Ukraine.

(Email: oleksiy.krasnorutskyy@ gmail.com)

Reznik N.P., National University of Life and Environmental Science, Kyiv, Ukraine. (Email: nadya-reznik@ukr.net)

Slobodianyk A.M., National University of Life and Environmental Science, Kyiv, Ukraine. (Email: slobodyanikann@gmail.com)

Guley S.A., Ternopil National Economical University, Ternopil, Ukraine.

\section{RESULTS}

Technology develops at an astonishing pace, and if earlier it had a greater influence on relatively new and high-tech industries, now the time has come for traditional and conservative businesses. The agricultural sector was no exception. But the list of technologies that will greatly influence on the development of this direction in the coming years is adjusted from year to year. Many technologies have already conquered farmers, but there is still a whole range of solutions that in the near future will be implemented into the agricultural industry.

1. Blockchain - is a distributed registry technology that cannot be changed, will simplify the life of many industries in the future. With the introduction of a single data exchange standard, the need for auditing financial statements and tax reporting will disappear, the number of papers will decrease, paperwork will accelerate, numerous checks will disappear, and the risk of fraud will decrease. Of course, this will touch the agricultural sector.

A good example of this is the recent announcement of the Louis Dreyfus Company [2], which sold 60000 tons of soybeans from the United States to the Chinese company Shandong Bohi Industry [3] using the Easy Trading Connect electronic platform. The international financial groups ING [4], Societe Generale [5] and ABN Amro [6] participated in this process.

Also, the official announcement of the global logistics company Agility [7] on the introduction of a cargo tracking system that was developed by IBM [8] and Maersk [9] based on distributed registry technology, was declared.

Recently, a group of researchers from MIT Media Lab [10] approached AgTech Ukraine [11]. They visited Ukraine to study the logistics processes in the trade of agricultural crops in the market. MIT Media Lab experts intend to incorporate the collected data into their open-source software platform built on Blockchain technology.

Now let's try to figure out exactly where in practice it will be possible to apply Blockchain technology. There are many options:

1. Registers. Today the first stage of the transfer of the State Land Cadaster in Ukraine to Blockchain technology has been completed, then this practice will be transferred to all state registries.

2. Traceability. The popularity of the trend of tracking products "from field to table" is growing every day and Blockchain is an excellent technology for building a system for monitoring the origin of goods.

3. Smart contracts. After a while, most of the standard contracts will be unified and converted into electronic form. 
This will speed up business processes, translate verification into electronic format and increase the security guarantees of contractual activities. Already, some electronic platforms for trading in agricultural products use this technology.

4. Asset tokenization - is an evolutionary continuation of the development of ICOs (Initial Coin Offering) as an alternative tool for raising funds for business development. Today it is possible to do this through a private issue of shares, IPO (Initial Public Offering) or sale of a business share to an investor, but the future is with new financing models.

5. Forward and futures contracts due to Blockchain technology are gaining a new level of popularity because of reduction in risk. Also, these tools can be used to attract working capital financing of the current activities of companies.

2. AR / VR - are virtual and augmented reality technologies. This is what will change the system of education and professional training in the near future. Already, large equipment manufacturers are introducing these technologies in their plants and this can significantly reduce the number of product defects, personnel errors and industrial injuries. In addition, this is a great way to use highly qualified specialists more efficiently, because with the help of virtual and augmented reality technologies, they can manage repair and service work in different parts of the world, being in one place. And AR / VR will help keep employees focused on routine processes through gamification.

3. Electric transport. We see an increase in the popularity of this type of transport in cities, but its distribution will also cover less densely populated areas. And if in urban conditions the main businesses that understood the benefits of using electric transport are delivery services and taxis, then in the rural areas the agricultural sector is actively interested in these technologies. This is because fuels and oil constitute a very significant part in the cost structure of most agricultural companies. Electric tractors are gaining popularity in Europe, and even the Ukrainian Kharkiv Tractor Plant has announced a whole range of electric drives [12]. So far, this technique is relevant for gardens and small farms, but the increase in capacity will not take long. The era of electric traction in freight traffic is also approaching. And of course, staff machines can also be electric. Last year, there was already a successful testing of such vehicles in several Ukrainian agricultural holdings and cooperatives.

Another niche is the development of charging stations that can be placed directly on electrical pylons. Ukrainian farmers were lucky, because power lines along, across and among fields are almost everywhere. There are also talented engineers who can organize everything in terms of hardware, but the task is more of a regulatory and organizational nature, since it is quite difficult to establish a charging station right in the field.

4. Energy-efficient data transmission technologies for sensors (for example, LoRaWAN [13], SigFox [14]) is promising direction for agriculture. The number of various sensors is growing every year in all directions, these are weather stations, soil moisture sensors, sensors for warehouses and storages, personnel and equipment identifiers, livestock trackers, indoor environmental sensors, security system indicators and so on. All these systems need data transmission channels, preferably wireless and energy-saving, since the power of information becomes noticeable only after its collection and analysis. Today in the Ukrainian agricultural sector there is already an order for the deployment of such networks from specific companies.

5. Computer Vision + Image Recognition - are perhaps the most promising niche in terms of technology development. By the way, here Ukrainian developers occupy leading positions. Data from satellites and drones are becoming more accurate, cameras are installed in most production facilities, all processes are monitored. And the next step in the development of mass production is the individualization of factor management at the level of the minimum controlled unit with a gradual increase in accuracy to a specific plant, animal, worker or operation. A good example of the development of these technologies is the attempt of large chemical companies to identify plant diseases from photos of affected leaves.

At this stage of development of technological innovations, the market of precision farming is most actively developing. Along with hardware and software, precision farming has been growing rapidly since 2014 with an indicator of 2.3 billion euros, in 2018 it amounted to 3.7 billion euros, and by 2020 it is expected to grow to 4.5 billion euros with $12 \%$ of CAGR (Compound annual growth rate) [15]. The potential of the precision farming market exceeds even the global agricultural equipment market, which is growing at a much slower pace with $4 \%$ of CAGR till 2.4 million vehicles in 2020 (Table I).

Table- I: Market estimation of Precision Farming 2014-2020, EUR bn

\begin{tabular}{|l|c|c|c|c|c|c|c|c|c|}
\hline Years & $\mathbf{2 0 1 4}$ & $\mathbf{2 0 1 5}$ & $\mathbf{2 0 1 6}$ & $\mathbf{2 0 1 7}$ & $\mathbf{2 0 1 8}$ & $\mathbf{2 0 1 9}$ & $\mathbf{2 0 2 0}$ & $\mathbf{2 0 1 4 - 2 0 2 0}$ \\
\hline \multirow{2}{*}{$\begin{array}{l}\text { All } \\
\text { regions }\end{array}$} & 2,3 & 2,6 & 3,0 & 3,3 & 3,7 & 4,1 & 4,5 & CAGR, \% \\
\cline { 2 - 8 } & 1,2 & 1,3 & 1,4 & 1,5 & 1,6 & 1,6 & 1,6 & $5 \%$ \\
\hline $\begin{array}{l}\text { North } \\
\text { America }\end{array}$ & & & & & & & & \\
\hline Europe & 0,4 & 0,5 & 0,6 & 0,7 & 0,8 & 0,9 & 1,0 & $15 \%$ \\
\hline Asia & 0,2 & 0,3 & 0,4 & 0,5 & 0,6 & 0,7 & 0,8 & $21 \%$ \\
\hline $\begin{array}{l}\text { South } \\
\text { America }\end{array}$ & 0,2 & 0,2 & 0,3 & 0,4 & 0,4 & 0,5 & 0,6 & $20 \%$ \\
\hline $\begin{array}{l}\text { Rest of } \\
\text { world }\end{array}$ & 0,2 & 0,2 & 0,3 & 0,3 & 0,4 & 0,5 & 0,5 & $21 \%$ \\
\hline
\end{tabular}

In regions with low starting positions in the development of precision farming, the highest growth rates will subsequently be observed. At this stage of the world economy the most promising markets are the regions of the USA, Canada and European countries.

The North American market is characterized by large agricultural land and a high labor price, which agrees farmers to apply precision farming and reduce their costs with the help modern technology.

The European market is characterized by the use of technology in combination with a professional workforce. This result is not least provided by the system of public and private investment. 
The remaining regions are faced with the problem of adverse climatic conditions, combined with an increase in food consumption. Therefore, there is a high growth rate of precision farming, because nowhere else are all the necessary methods for increasing land productivity required so much. However, the insufficient number of specialists, poor infrastructure and poor attractiveness of the agricultural sector due to low salaries hinder the implementation of modern technologies.

The promise of precision farming motivates new players in this market to come up with innovations, occupying a new appeared niche in the technology market. They can dictate the prices of their goods and improve the old by combining them into a single product that meets a wider range of needs of farmers. Roland Berger's [16] research made its own forecast of future in technology development (Table II).

Table- II: Technology roadmap 2010-2030

\begin{tabular}{|c|c|c|c|c|c|c|c|}
\hline & $\begin{array}{c}2010 \\
- \\
2015\end{array}$ & $2015-$ & $\begin{array}{l}2020- \\
2025\end{array}$ & \multicolumn{2}{|c|}{$2025-$} & \multicolumn{2}{|c|}{$2030-\ldots$} \\
\hline \multirow[t]{4}{*}{$\begin{array}{l}\text { Automation } \\
\text { \& robotics }\end{array}$} & \multicolumn{5}{|c|}{$\begin{array}{c}\text { Auto-guidance with GPS (incl. reference } \\
\text { station) and reinforced by laser/infrared } \\
\text { sensors }\end{array}$} & \multirow[t]{3}{*}{-} & \\
\hline & \multicolumn{5}{|c|}{$\begin{array}{l}\text { Variable rate applications improved by } \\
\text { precise yield maps }\end{array}$} & & \\
\hline & - & \multicolumn{4}{|c|}{$\begin{array}{c}\text { Automatic machine setting } \\
\text { optimization (harvesting and } \\
\text { implements) }\end{array}$} & & \\
\hline & \multicolumn{2}{|c|}{-} & \multicolumn{2}{|c|}{$\begin{array}{c}\text { Machine } \\
\text { platoon }\end{array}$} & \multicolumn{2}{|c|}{$\begin{array}{l}\text { Highly } \\
\text { automate } \\
\mathrm{d} \\
\text { machines }\end{array}$} & \\
\hline \multirow[t]{5}{*}{$\begin{array}{l}\text { Imagery \& } \\
\text { sensors }\end{array}$} & \multicolumn{2}{|c|}{$\begin{array}{l}\text { Aerial imagery } \\
\text { (satellite/drones) }\end{array}$} & $\begin{array}{r}\mathrm{Mu} \\
\text { is } \\
\mathrm{c}\end{array}$ & $\begin{array}{l}\text { funct } \\
\text { lity } \\
\text { nes }\end{array}$ & \multicolumn{2}{|c|}{-} & \\
\hline & - & $\begin{array}{c}\text { Basic } \\
\text { crop } \\
\text { conditio } \\
n \\
\text { sensors } \\
\text { (optical) } \\
\end{array}$ & \multicolumn{4}{|c|}{-} & 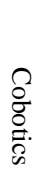 \\
\hline & \multicolumn{2}{|r|}{-} & \multicolumn{4}{|c|}{$\begin{array}{l}\text { Advanced crop condition } \\
\text { sensors (incl. plant health) }\end{array}$} & \\
\hline & \multicolumn{2}{|c|}{$\begin{array}{c}\text { Soil condition } \\
\text { measurement }\end{array}$} & \multicolumn{4}{|c|}{-} & \\
\hline & \multicolumn{2}{|c|}{\begin{tabular}{c|c} 
Location & \\
yield & \\
monitoring & \\
\end{tabular}} & \multicolumn{2}{|c|}{$\begin{array}{l}\text { On-machine soil } \\
\text { condition sensors }\end{array}$} & & - & \\
\hline \multirow[t]{4}{*}{$\begin{array}{l}\text { Big data \& } \\
\text { digitalization }\end{array}$} & $\begin{array}{l}\text { Field } \\
\text { yield } \\
\text { maps }\end{array}$ & - & \multicolumn{4}{|c|}{ Augmented reality } & \\
\hline & - & \multicolumn{5}{|c|}{$\begin{array}{l}\text { Multi-layer field maps and } \\
\text { data analytics }\end{array}$} & \\
\hline & - & \multicolumn{4}{|c|}{ OEM data platforms } & - & \\
\hline & . & & Open dat & latforn & & & \\
\hline $\begin{array}{c}\text { Bio- } \\
\text { engineering }\end{array}$ & \multicolumn{6}{|c|}{$\begin{array}{c}\text { Seeds transformation based on field } \\
\text { data analytics }\end{array}$} & \\
\hline
\end{tabular}

According to Table II, all agricultural processes will be automated anyway, and further development of technologies and the use of various innovations will lead humanity to bioengineering, which at this stage of human development seems like a shot from a futuristic movie.

Now the application of precision farming covers a wide range of areas of activity, including the post-harvest phase (Table III).
Table- III: Strategic control points along the agricultural value chain

In scope of precision farming

\begin{tabular}{|c|c|c|c|}
\hline \multicolumn{4}{|c|}{ In scope of precision farming } \\
\hline \multicolumn{2}{|c|}{ Input supplying } & Production & Post-harvest \\
\hline $\begin{array}{l}\text { Machinery } \\
\text { prescription }\end{array}$ & $\begin{array}{c}\text { Fleet } \\
\text { distribution }\end{array}$ & $\begin{array}{c}\text { Land } \\
\text { preparation }\end{array}$ & Storage \\
\hline $\begin{array}{l}\text { Preventive } \\
\text { maintenance }\end{array}$ & Fleet rental & Planting & $\begin{array}{c}\text { Transportatio } \\
\text { n }\end{array}$ \\
\hline $\begin{array}{c}\text { Remote } \\
\text { diagnosis }\end{array}$ & $\begin{array}{c}\text { Fleet } \\
\text { management }\end{array}$ & Irrigation & Food pricing \\
\hline $\begin{array}{c}\text { Seeds } \\
\text { prescription }\end{array}$ & $\begin{array}{c}\text { Inputs } \\
\text { providing } \\
\text { (fertilizer) }\end{array}$ & Fertilization & $\begin{array}{l}\text { Food } \\
\text { branding }\end{array}$ \\
\hline $\begin{array}{c}\text { Seeds } \\
\text { transformati } \\
\text { on } \\
\end{array}$ & Soil analysis & $\begin{array}{c}\text { Field } \\
\text { monitoring }\end{array}$ & $\begin{array}{l}\text { Commodity } \\
\text { trading }\end{array}$ \\
\hline $\begin{array}{c}\text { Climate } \\
\text { prediction }\end{array}$ & $\begin{array}{l}\text { Insurance } \\
\text { (weather) }\end{array}$ & Harvesting & $\begin{array}{c}\text { Insurance } \\
\text { (production) }\end{array}$ \\
\hline $\begin{array}{c}\text { Data } \\
\text { analytics } \\
\text { (big data) }\end{array}$ & $\begin{array}{l}\text { Remote } \\
\text { sensing }\end{array}$ & $\begin{array}{c}\text { Transportati } \\
\text { on }\end{array}$ & $\begin{array}{c}\text { Infrastructure } \\
\text { investment }\end{array}$ \\
\hline $\begin{array}{l}\text { Satellite/dro } \\
\text { ne mapping }\end{array}$ & $\begin{array}{c}\text { Education/ } \\
\text { training }\end{array}$ & Storage & - \\
\hline \multicolumn{4}{|c|}{ Not in scope of precision farming } \\
\hline \multicolumn{2}{|c|}{ Processing } & \multicolumn{2}{|c|}{ Distribution/marketing } \\
\hline \multicolumn{2}{|c|}{ Food processing } & \multicolumn{2}{|c|}{ Commercialization } \\
\hline \multicolumn{2}{|c|}{ Food packaging } & \multicolumn{2}{|c|}{ Supply chain management } \\
\hline \multicolumn{2}{|c|}{ Food transportation } & \multicolumn{2}{|c|}{ Food marketing } \\
\hline \multicolumn{2}{|c|}{ Food traceability } & \multicolumn{2}{|c|}{ Online shopping } \\
\hline \multicolumn{2}{|c|}{$\begin{array}{c}\text { Supply sources } \\
\text { management }\end{array}$} & \multicolumn{2}{|c|}{-} \\
\hline
\end{tabular}

\section{DISCUSSION}

The speed of technology development directly depends on its profitability for the business. Therefore, there are several directions for obtaining this profit through the provision of new services:

1. The role of technology integrator. There will be many technologies on the market, the amount of which can be confusing. It will be promising to create consulting firms that will be able to select the optimal system for a specific task of the company, to train employees of the client company to be operators of new systems.

2. Providing warranty service for the installed system. Often the installers of certain systems, for example, fire safety, security and video surveillance, (in our case, the agricultural service system) do not always provide service of installed system, especially after the warranty period, therefore this niche will be free for go-ahead firms.

3. Business consultations on crops. In addition to consultations for installing equipment, it can be provided consultations on the selection of the type of seeds and crops, the demand for which is expected by the time of harvest. Such firms can forecast profit and take a percentage of this profit for its services. 
4. Specialists of Big Data. At a certain stage in the development of technologies, it will be necessary to attract specialists who can correctly use the information accumulated by satellites and drones, and also process them using certain programs.

5. Trading. This niche is not so futuristic as the previous, but it will be no less relevant in the future. The use of technologies will bring agricultural companies to a new level of competition, so it will be necessary to use the services of professional traders who can profitably sell the crop, taking into account the appearance of new technologies and its implementation by other competitors of the market. In addition to the amount of harvested crop, a new factor may appear that is the rate of ripening of this crop. Accordingly, futures contracts and insurance transactions will become even more relevant in the face of fierce competition.

\section{CONCLUSION}

The technologies are actively developing and due to this, new agricultural giants may appear on the market. Small companies that are no longer afraid to implement technological innovations may soon become leaders of the agricultural market. And large companies, on the contrary, lose its positions, because they have not used its resources so optimally, even if they have a larger agricultural land. Future novelties will be relevant for all spheres of human production, but in the face of the arising food crisis due to the progressive growth of the world's population, they are simply necessary precisely in the agricultural sector. Therefore, the introduction of at least the most accessible new products should already be thought out by all representatives of the agricultural business, so as not to be left behind its competitors.

\section{REFERENCES}

1. Official website of Food and Agricultural organization of United Nation. Available at: 〈http://www.fao.org >

2. Official website of Louis Dreyfus Company. Available at: < https://www.ldc.com>

3. Official website of Shandong Bohi Industry. Available at: < http://www.bohi.com.cn/>

4. Official website of ING group. Available at: < https://www.ing.com/>

5. Official website of Societe Generale. Available at: < https://www.societegenerale.com/>

6. Official website of ABN Amro. Available at: < https://www.abnamro.com/>

7. Official website of Agility Logistics. Available at: < https://www.agility.com/>

8. Official website of IBM. Available at: < https://www.ibm.com/>

9. Official website of Maersk. Available at: < https://www.maersk.com/>

10. Official website of MIT Media Lab. Available at: < https://www.media.mit.edu/>

11. Official website of AgTech Ukraine. Available at: < https://agtech.com.ua/>

12. Official website of Kharkiv Tractor Plant. Available at: < http://xtz.ua/en/news/>

13. Official website of LoRaWAN. Available at: < https://lora-alliance.org/>

14. Official website of SigFox. Available at: < https://www.sigfox.com/>

15. Business opportunities in Precision Farming: Will big data feed the world in the future? Report of Roland Berger
Strategy Consultants. Available at: < file:///C:/Users/38098/Downloads/roland_berger_busines s_opportunities_in_precision_farming_20150803.pdf>

16. Official website of Roland Berger. Available at: < https://www.rolandberger.com/> 